\title{
How to Implement the Savi Learning Model for Students with Reading Difficulties
}

\author{
Aldjon Nixon Dapa ${ }^{1, *}$, Henny B. A. Kiriweno ${ }^{2}$ \\ ${ }^{1}$ Education Faculty, Universitas Negeri Manado, Jl. Kampus FIP Unima Matani 1, 95445, Tomohon, Indonesia \\ ${ }^{2}$ Principal at SLB Paulus Tomohon, Jl. Rok-rok Matani 1 Tomohon, 95445, Tomohon, Indonesia
}

Received July 9, 2019; Revised September 9, 2019; Accepted September 16, 2019

Copyright $\bigcirc 2019$ by authors, all rights reserved. Authors agree that this article remains permanently open access under the terms of the Creative Commons Attribution License 4.0 International License

\begin{abstract}
The purpose of this action research is to describe the application of the SAVI learning model and learning for continuous students to learn to read in the fourth grade of Tomohon State Elementary School II and SD GMIM III Tomohon. The method used in this study is action research. Action research provides useful answers for teachers or educators in conducting studies in a school and providing input that requires help to improve what has been done real. This study uses the Elliot model with quantitative and qualitative research (mixed methods) in the field of data analysis. Based on the results of the assessment, discussion of researchers with collaborators, and achievements of student learning outcomes in each cycle, it can be concluded that: a) Thematic learning outcomes and learning in sustainable students in grade IV of Tomohon Elementary School II and SD GMIM III Tomohon can be searched through the application of the SAVI learning model, b) The learning process that applies the SAVI Learning Model is able to overcome the difficulties of students, namely learning continuous difficulties for subject matter with moving learning, understanding, listening and thinking to improve learning and learning outcomes improve.
\end{abstract}

Keywords SAVI Learning Models, Students with Reading Difficulties, Learning to Read

\section{Introduction}

Reading skills are the basis for mastering various sciences. If children at early school age do not immediately have reading skills, they will experience many difficulties in learning various fields of science in the following classes. (1).

Reading is one of the academic skills that students must have at school. This skill is one skill that influences the academic success of students. To be able to understand a concept of science, students must have reading skills, because reading skills are basically one of the main material in Indonesian language subjects, and then students are used to understand the various knowledge they will learn. (1).

Furthermore, according to Abdurahman, reading is a skill that must be taught since students enter elementary school, therefore if students experience difficulty reading they must be overcome as soon as possible, because reading is a capital for learning. (1).

Therefore there are five stages of reading development, namely (1) readiness readiness, (2) beginning reading, (3) speed reading skills, (4) extensive reading, (5) real reading.

The stage of reading readiness covers the period of time from birth until reading lessons are given, generally during the first grade of elementary school. The initial reading phase starts from class I elementary school, namely when children are six years old, including children who have learned to read earlier and children who learn to read at the age of seven and eight years. The speed reading phase generally occurs when the child sits in class II or III, and at this stage is expected to understand the relationship of sound-symbols. The broad reading stage generally occurs when children have been in grade IV or V elementary school, at this stage children are expected to enjoy and enjoy reading. While at the reading stage actually occurs when students sit in class VI, at this stage it is expected that children can understand correctly what they are reading.

Reading skills can develop if done with a lot of practice regularly. To improve reading skills among students there must be a design or learning model that is able to motivate them to review the latest findings, both those that are related to their field of study and other fields of study.

Based on the results of preliminary observations in class IV of SD Negeri II Tomohon, a number of students found it difficult to understand the contents of the reading 
empirically. Their prevalence is $10.5 \%$ of the total student population in one class. This amount certainly affects the learning climate. In addition this difficulty will have an impact on the development of students to understand various knowledge and skills in other fields of science.

Because the difficulty of reading comprehension is identified, among others: (1) difficulties in determining the main ideas and paragraph explanatory ideas, (2) difficulty in determining the sentence relationship in the reading, and (3) difficulty in determining the facts in the reading.

The existence of difficulties experienced by students in understanding the contents of the reading is allegedly as a result of the implementation of reading comprehension learning which still often uses conventional learning strategies, even tends not to use media. Reading learning models used by teachers such as assignment models,procedures closure, numbered heads and jigsaw.

Based on observations, it can be seen that, in the implementation of learning, students only read what is written on the board by the teacher, then copy it to the notebook, reread it in turns, or read the textbook on the teacher's instructions. There is no task to read other books or other reading media that can be accessed outside of school.

The learning situation built tends to be classical and there have not been many innovative efforts to overcome the shortcomings of the classical model. Teachers also still have limited understanding and ability in choosing learning models that can improve students' reading comprehension skills.

In the opinion of Lerner and Zipprich Mary Ann, and Stephane classify coping strategies for the difficulty of reading into two groups, namely strategies that aim to improve the ability to recognize and read smoothly, and strategies that aim to improve reading comprehension skills. (2).

Whereas according to Sutikno, experience proves that learning failure is one of them caused by the selection of an incorrect model or method. (3) Classes that are less conducive and the conditions of students who are less creative due to the determination of methods that are not in accordance with the nature of the material, and not in accordance with the learning objectives. The more appropriate the methods used by the teacher in learning, the more effective the achievement of learning goals is expected.

The introduction of various innovative learning models is an obligation for a teacher. With the various developments that are happening now, of course, it requires adaptation actions from the teacher to be able to carry out more effective learning. This is in line with the opinion of (4). that in language learning, today, there are many learning models available. In fact, many language learning models are adopted by other fields of study. However, why many Indonesian Language teachers are still having difficulties in varying the Indonesian language learning model. Many of them only focus on lectures, discussions, and assignments.

In general, with a variety of learning development activities that are often followed by teachers, it gives an opportunity for teachers to be able to get to know various innovative learning models. According to (5), various learning strategies can be carried out to help develop the reading ability of students having difficulty learning to read, because the difficulty of learning to read is a condition of learning barriers that continue to stick, so one of them requires the right learning model. Therefore, teachers need to master and apply learning models that are appropriate to the characteristics of students having difficulty learning to read.

The lack of optimization of learning in children with learning difficulties is also evident in the teacher's lack of service in learning that is tailored to the characteristics and needs of the child. This is seen based on observations and interviews conducted by researchers that the teacher's strategy in dealing with children has difficulty learning to read only by giving additional assignments or homework assignments, which are actually not in accordance with the interests, learning styles, and thinking styles of students. The implications of this action make students not enthusiastic, lazy, not motivated to learn, and tend to get low learning outcomes.

There are several learning models that can actually be used to serve education for children with reading difficulties, one of which is the SAVI learning model. SAVI Learning is an acronym of Somatis (physical), Auditory (sound), Visual (image), and Intellectual (contemplative). (5). According to Meier, if a learning can involve all these SAVI elements, learning will take place effectively as well as attractively.

\section{Literature Review}

\subsection{Research Concept Action}

Research Action has more scope than classroom action research, because the object of action research is not only limited to the class, but outside the classroom, such as organizations, communities, and society. The knife of analysis from action research is that the system is not just a subsystem of so many series of educational problems. Educational research lately pays considerable attention to action research. This research is believed to be able to offer new approaches and procedures that are more promising and have a direct impact on the improvement and enhancement of the professionalism of education actors in managing the learning process.

Action research according to Mills (2003) is systematic research carried out by researchers, teachers, principals, advisors or stakeholders otherin the learning environment to gather information about the ways in which their schools 
are run, how they teach and how well their students / students learn. Action research provides useful answers for teachers or educators in conducting studies in a school and provides valuable input for improving the quality of what has been done in real terms (Mills, 2003).

Action research according to Kemmis and Taggart cited by Denzin and Lincoln (2009) is a form of collective and self-reflective research conducted by participants in social situations to improve their educational and social practices, as well as their understanding of their performance, which includes a spiral self reflective cycle in the form of; plan a change, study and observe the process, review the process and consequences, then re-plan again, study and observe, review, and so on (Denzin \& Lincoln, 2009).

While Suharsimi Arikunto, et al. Stated that action research is an observation of learning activities in the form of an action that is deliberately raised and occurs in a class together (Arikunto, Suhardjono \& Supardi, 2008). The action is given by the teacher or by the direction of the teacher carried out by the learner. Furthermore Suharsimi also stated that action research is carried out through four main steps, namely (a) planning, (b) action, (c) observation, and (d) reflection (Arikunto, Suhardjono \& Supardi, 2008). The four main interrelated steps in conducting research action is called a cycle.

Zuber and Skerrit suggested action research as a collaborative activity, an important independent discovery carried out by practitioners (teachers, school administrators) on important issues in the learning practices they carry out (Zuber, Ortrun \& Sekerrit, 1996). They have problems and feel responsible for solving these problems through teamwork by running the cycle process as follows: (1). Planning activities, (2) implementing actions, (3) observations, (4) reflection. According to Susilo, in general there are four main stages in action research, namely: 1) planning, 2) implementation, 3) observation, and 4) reflection. (Susilo, 2007).

Action research is a trial of ideas in the form of practice in the hope that they are able to develop or change things, trying to have a real influence on certain situations. As Hopkins stated below: "Action research is trying to come up with ideas in practice with a view to improving or changing something, trying to have a real effect on the situation". ” (11). Next Coghlan gives the understanding "action research is a participatory, democratic process concerned with developing practical knowing in the pursuit of human purpose, grounded in a participatory worldview". (Brannick, Coghlan, 2005). Based on the two meanings above, it can be concluded that action research is dynamic, namely the change in real activities in routine situations, and also an attempt to find useful goals for the benefit of life in the world.

Another definition described by Stephen Kemmis as follows:

"Action research is a form of collective self-reflective research carried out by participants in social situations to improve reasoning / rationality and fairness of their educational practices and social practices as well as their understanding of their practices and to the situation where these practices are carried out " (11).

Based on some of the opinions above, it is implied that action research is actually based on a philosophy that there is self-awareness in humans to improve performance in the form of practice, realize lack of self, and certainly want to make improvements, and want something better .

\subsection{Learning Difficulties}

The term children with learning difficulties is quite diverse. This diversity of terms is caused by different expert perspectives. The group of medical experts call it the term brain injured, and minimal brain disorder and in the field of education there are those who call it the term educational handicapped. But the term that is often used by education experts in general is learning disabilities which are interpreted as "learning difficulties".

In etymology studies, the difficulty of learning to read is often called the term dyslexia. Dyslexsia comes from Greek which consists of two words, namely the word dys and lexia. The word dys means not capable and the word lexia means reading. So dyslexia can be interpreted as a condition, a form of difficulty or inability to learn to read. (13)

Therefore, some experts explain the notion of dyslexia with the same concept. Mercer (Cecil, and Mercer-Ann , 1989), defines dyslexia as a syndrome of difficulty in learning components and sentences integrating components of words and sentences, and in learning everything related to time, direction, and time. Whereas according to Critchley (13), dyslexia is defined as: (a) a disorder in children even though conventional learning experiences fail to achieve language skills such as reading writing and spelling commensurate with their intellectual abilities, and or (b) a disorder which is manifested through difficulties in learning to read even though it obtains conventional learning, has adequate performance, and has socio-cultural opportunities. According to Myklebust and Johnson, there are several characteristics of children having learning difficulties, namely as follows: (1) experiencing deficiencies in visual and auditory memory, shortcomings in short and long term memory; (2) having problems in remembering data such as remembering the days of the week; (3) having problems recognizing the left and right directions; (4) have deficiencies in understanding time; (5) if asked to draw people it is often incomplete; (6) poor spelling; (7) difficult to interpret globe, maps, or graphics; (8) deficiencies in coordination and balance; (9) difficulties in counting; (10) difficulties in learning foreign languages. (14).

The characteristics of students having difficulty learning to read vary greatly depending on the nature of the problem. Saunders explained the characteristics of students having difficulty learning to read as follows: (1) reading slow, up 
and down intonation, and word for word; (2) often reverse letters and words; (3) changing letters in words; (4) chaotic with words that are only slightly different, for example: smell, fruit, stone, blind; and (5) often guessing and repeating words and phrases. (15). Furthermore, according to Mercer, there are four characteristic groups of reading difficulties, which are related to: (1) reading habits (2) misunderstanding of words, (3) misunderstanding and (4) allergy symptoms (15).

More broadly the characteristics of dyslexic children according to Ekwall and Shanker have several symptoms related to cases of severe reading difficulties: (1) Reversal of letters and words; (2) Increasing the word has difficulty or does not improve after reading without sound (inwardly) or reading the first oral (orally), (3) the inability to store information in memory until time is needed, (4) difficulty in concentration, (5) inability to see relationships, (6) unstable emotions (labile), 7) impulsivity (carelessness), (8) poor eye hand motor coordination, (9) difficulty in sequencing, (10) inability to work correctly, (11) omission of words about phrases, (12) chaos related to reading verbally (oral), (13) weak auditory discrimination, (14) poor in syntax (grammar), stuttering, and interrupted speech break up / stop, (15) learning achievement in counting is higher than in reading and spelling and, (16) hyperactivity. (Yusuf, 2005)

Various reading errors that have been put forward can be used by the teacher as a reference in conducting identification and assessment, as well as being a reference in improving learning.

In the world of education the termused educational handiccaped is because these children experience difficulties in following the educational process so that they need educational services specifically in accordance with the type and degree of difficulty. The special education service in question is also related to the strategy or approach to its assistance.

Children with learning disabilities are students who have normal or above normal intelligence but have difficulty with one or more aspects needed for learning. The difficulty is caused by the occurrence of mild dysfunction in the central nervous system or minimal brain disfunction. According to the Federal definition put forward by Lovitt, what is meant by special learning difficulties is an irregular condition in one or more basic psychological processes that involve understanding or using language, oral or written that can be manifested in the imperfections of listening, thinking, speaking , reading, writing, spelling and / or doing mathematical calculations. This term also includes conditions such as experiencing difficulty / obstacle perception, brain injury, minimal brain dysfunction, dyslexia, and developmental aphasia. This term does not include children who have learning problems caused by vision, hearing, or motor disorders, or mental retardation, or emotional disturbances, or those caused by environmental, cultural or economic disadvantages ( Lovitt, 1989)

\subsection{Inclusion Learning}

Permendiknas No. 70 of 2009 states that inclusive education is a system of education that provides opportunities for all students who have abnormalities and have the potential of intelligence and / or special talents to participate in learning or education in an educational environment together with students in general. So in inclusive education students with special needs can learn together with other students in regular schools.

Inclusive education is an education service system that includes children with special needs learning together with their peers in regular schools closest to where they live. (16). Inclusive schools are schools that provide services with appropriate, challenging education programs. and accommodates all students in the same class. But the assistance and support provided by the teachers is tailored to the abilities and needs of each student so that the children succeed (17).

Inclusive schools are new developments in integrated education. In every student's inclusive school according to their specific needs, all efforts can be optimally served by making various modifications and / or adjustments, starting from the curriculum, facilities and infrastructure, teaching staff and education, learning systems to the scoring system. All students in inclusive education programs will get the same treatment in schools, which distinguishes students with special needs from getting a special assistant teacher. (16)Through inclusive schools students are taught diversity and tolerance among students, where they are taught to develop mutual respect for the physical differences between regular students and students with special needs in various aspects of life. (18). In addition, students with special needs in inclusive schools have the same rights and obligations as other regular students and do not get special treatment from the teacher, but they are supervised by a special assistant teacher.

According to Margaret E. King-Sears (2001) the purpose of curriculum modification and learning in inclusive classes is to compensate for intellectual, physical, or behavioral challenges and to create a learning environment that allows individuals with disabilities to use existing skills. (19).

Furthermore, according to Margaret E. King-Sears (2001), curriculum modification models in inclusion classes can be categorized into four types, namely: (a) accommodation, (b) adaptation, (c) parallel curriculum results, and (d)overlapping curricula (19)

Thus learning is an effort to create a condition for the creation of a learning activity that allows students to gain learning experience (20). Furthermore De Houwer explains learning functionally as a behavior change that results from experience (21). In line with the opinion above Baron et al. Defines learning as behavior change (22). Thus learning is a learning process that is planned and attempted to achieve a defined learning goal so as to cause changes in students. 
Learning which is a learning process will only occur if students are active in the learning process. Therefore students are one of the important components in a learning process or can be said by students as the subject of learning. Every student has different learning characteristics and styles. For example, there are students who have intellectual abilities who need services to channel their talents, and there are also students who are less concentrated who have difficulty reading so that they need their own handling, but that does not mean they should only be served in schools with special needs, because there are schools that can meet the special needs of children children in public schools by changing curriculum and / or learning strategies. (23)

\section{Materials and Methods}

The general purpose of this action research is to overcome the problem of the learning process of reading in students the difficulty of learning to read, planning learning activities, carrying out learning activities and evaluating learning outcomes in students learning difficulties reading through the application of the SAVI learning model.

The specific purpose of this action research is to find out whether there is an increase in Indonesian language learning outcomes in reading learning difficulties in the fourth grade of Tomohon State Elementary School through learning that applies the SAVI learning model, and to determine the improvement of the learning process that includes learning, motivation , learning activities, student participation and social skills of students in learning Indonesian in class IV with the SAVI learning model.
The place of action research is planned at State Elementary School II in Tomohon City. This school was chosen because of one of the inclusive schools in Tomohon City. The time for conducting research from July 2017 to December 2018.

The method used in this study is action research. Action research provides useful answers for teachers or educators in conducting studies in a school and provides valuable input for improving the quality of what has been done in real terms.

This study uses action research methods with the Elliot model by combining quantitative and qualitative research (mix method) in the field of data analysis. Action research is aimed at increasing the effectiveness of learning which is the responsibility of the teacher, so that learning can be tailored to the needs and characteristics of students, especially students who have difficulty learning to read. This certainly will require commitment to participate and cooperation from all parties involved in the learning process in order to improve learning outcomes, especially students' reading skills.

\section{Results and Findings}

Based on the results of observations and interviews problems can be identified in: 1) the process of reading learning in students with learning difficulties that take place in class IV. 2) the characteristics of the type of reading difficulties in class IV 3 ) the initial ability and the difficulty of reading the understanding of students in class IV. The following is a description of the problems based on the results of observations and interviews;

Table 1. Prior Action Learning Process in Class IV

\begin{tabular}{|c|c|c|}
\hline No. & $\begin{array}{c}\text { Learning } \\
\text { Components }\end{array}$ & Description of Problems \\
\hline 1. & Curriculum & Individual curricula have not yet been prepared. Students have difficulty reading \\
\hline 2. & Students & $\begin{array}{l}\text { a. Having diverse characteristics includes the type of reading comprehension difficulties. } \\
\text { b. Not yet given the maximum service specific learning model or service is still given classically }\end{array}$ \\
\hline 3. & Teacher & $\begin{array}{l}\text { a. Teachers who teach } 2 \text { people, a teacher is a special tutor, but the learning process seems to have not } \\
\text { been effective. } \\
\text { b. Teachers dominate learning activities less involving student activity. } \\
\text { c. The method used is only lectures and questions and answers. } \\
\text { d. Less use of media and teaching aids } \\
\text { e. Teachers Special counselors have not compiled individual curricula for students having difficulty } \\
\text { reading }\end{array}$ \\
\hline 4. & Learning Methods & $\begin{array}{l}\text { a. Learning methods are less varied and have not been adapted to the characteristics of students. } \\
\text { b. The approach is still done classically, it has not varied according to the characteristics of students } \\
\text { a. The teacher does not involve all the potential of students in reading comprehension skills }\end{array}$ \\
\hline 5. & Learning Media & $\begin{array}{l}\text { a. Not yet utilizing learning media that are at school to the maximum } \\
\text { b. There is no learning media created by the teacher to explain the concepts that will be taught to students. }\end{array}$ \\
\hline 6. & Students' parents & $\begin{array}{l}\text { a. Not yet involved in the preparation of individual curricula for students having difficulty reading. } \\
\text { b. Not yet involved in the learning process to help students who have not been able to understand reading } \\
\text { c. In some cases there are still parents who are less communicative, making it difficult for the teacher to } \\
\text { solve the child's behavioral and emotional problems in school. }\end{array}$ \\
\hline 7. & Assessment & $\begin{array}{l}\text { There is no target for assessment of reading comprehension ability that is adjusted to the abilities and speed of } \\
\text { students. }\end{array}$ \\
\hline
\end{tabular}




\section{B. Cycle 1}

\section{Planning(Planning)}

Planning activities in learning through the SAVI learning model for students having difficulty learning to read in class IV are arranged based on: 1) identification of the learning process in the classroom. 2) identification of behavioral characteristics and initial abilities of students. 3) identification of student reading difficulties, 4) curriculum / learning objectives and individual teaching programs. The components of these objectives are integrated and adapted to the material / subject matter on the theme being carried out.

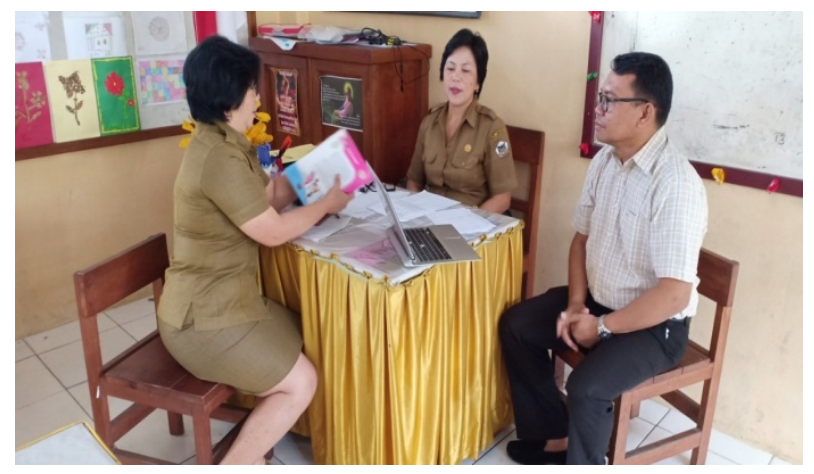

Figure 1. Discussion for Preparation of RPP

\section{Action(Acting)}

Implementation of Actions in cycle 1 began on September 4, 2017. Activities were carried out in class IV with 24 students. The schedule for Sub Theme 1 lessons starts at 7:30 a.m. WIB until 11:30 a.m. WIB.

Activities in implementing these actions include: 1) Learning Implementation Preparation, 2) Learning Implementation, 3) recording the learning process and children's behavior during learning.

\section{1). Preparation for Learning Implementation}

In the preparation activities for the implementation of learning researchers and teachers prepare the position of tables and chairs that will be occupied by 4th grade students according to the groups that have been determined. In this group setting it is also delivered to students with reading difficulties to adjust and blend in groups. From this arrangement, it was seen that all students were happy and accepted about the group division.

In this preparatory activity it was also determined that the teaching was the mother of NP, accompanied by the Madam SL, while the researcher became a collaborator who would take notes, observe, analyze during the learning activities taking place, and provide input, direction after the learning took place. The second learning preparation activity is to prepare learning media that will be used in learning, namely cultural maps in Student Books.

2). Implementation of Learning

The implementation of mathematics learning in class IV is thematic, in the implementation of learning refers to sub-theme 1 - Diversity of My Nation Culture. The activities in the implementation of learning begin by checking the readiness of students having difficulty reading in each group. One by one the teacher asks and analyzes the behavior of each student having difficulty learning to read before learning activities are carried out. Based on the results of the assessment, the discussion of researchers with collaborators at the beginning of learning was determined that in learning activities the control of changes in reading ability continued to be carried out with reasons to direct, guide, determine reading skills that must be improved.

After giving a positive suggestion the NP teacher invites students to be involved in each stage of learning that has been prepared at the beginning of the activity. The initial activity was carried out with apperception and a brief question and answer about the Beautiful Reading of Togetherness. In this activity the teacher asked the origin of a number of students, "Where did you come from?" Andrew answered "I am from Jakarta, ma'am," if where is Joshua from? "," I am from Tomohon bu ". Well, our children should be proud that even though we are from different tribes, we are still one in this class. "Are you happy to have friends from various tribes?", All students answered: "happy mom". Now our material about "the beauty of togetherness", observe the cultural map images of differences in traditional clothes, traditional houses, traditional dances, and traditional musical instruments, in your book.

There is active interaction between teacher and students in exploring topics or concepts that will be studied. In this activity, there were some active students who answered, and there were two students who tended to talk. To motivate the DM and MM to be actively involved in the learning of SL teachers, assisted by researchers tried to shift their focus, so they returned to paying attention to Ms. NP. This activity lasts for approximately 10 minutes. After that the teacher explained the cultural map of the differences in traditional clothes, traditional houses, traditional dances, and traditional musical instruments, students listened seriously.

Then the core learning activities are carried out. In this activity with the material prepared, the teacher goes around to find out if there are students who have difficulty completing the task. The teacher tries to facilitate the difficulties experienced by students with reading difficulties in each group assisted by Ms. SL. Students are quite helped by the media prepared by the teacher. After that the students are busy completing the assignments in the student book, while discussing with their group friends.

The next activity is the students read the text "Know the Minang Tribe". The teacher assigned each group to read the text, AK students got reading assignments in group I, as well as FM students in group 3, then JT students in group 4, although with the help of friends in the third group the 
students bravely were able to read text content reading to completion, which was greeted with applause from his friends. This situation makes them more confident and eager to be involved in further learning.

After reading the reading text, students are assigned to take important information from the text they read and write it in the form of a mind map. Each student makes their mind map in their respective books. At work, VP and JS students were seen, twirling the books they had, it seemed they seemed confused about what to write. Then the NP teacher approached them then gave guidance. Likewise with JN and GT students, they often ask questions about a number of paragraphs that they have not yet understood, the SL teacher then helps them by giving directions, steps they must write in the student book.

Before closing the lesson, students are directed to pack their own learning tools, namely: (1) taking their own bag, (2) opening the zipper bag; (3) insert a book, insert a pencil and other tools into a pencil holder, then put it in a bag, (4) close the zipper back of the bag. This activity is carried out in addition to familiarizing students with discipline, neat and orderly. It is also expected that children can carry out activities using their own bags without the help of others aimed at children's independence. After the child finishes packing the teaching and learning activities ends with giving questions to each student about the material that has been studied, for students who can answer the questions of the teacher, then they are allowed to rest.

\section{Observation (Observing)}

a. Observation of Learning Activities in Class IV Observations before the action began on August 21,
2017 until August 29, 2017. While observations on the implementation of silkus 1 learning began on September 4, 2017 until September 26, 2017. After the implementation of actions in cycle 1 began to appear changes and improvements in reading learning, learning activities both on the aspects of the teacher, students having difficulty learning to read, the media, and implementing the SAVI learning model. Previously the teacher dominated the class more in this action activity. It was seen that the teacher began to involve many students to be active in learning.

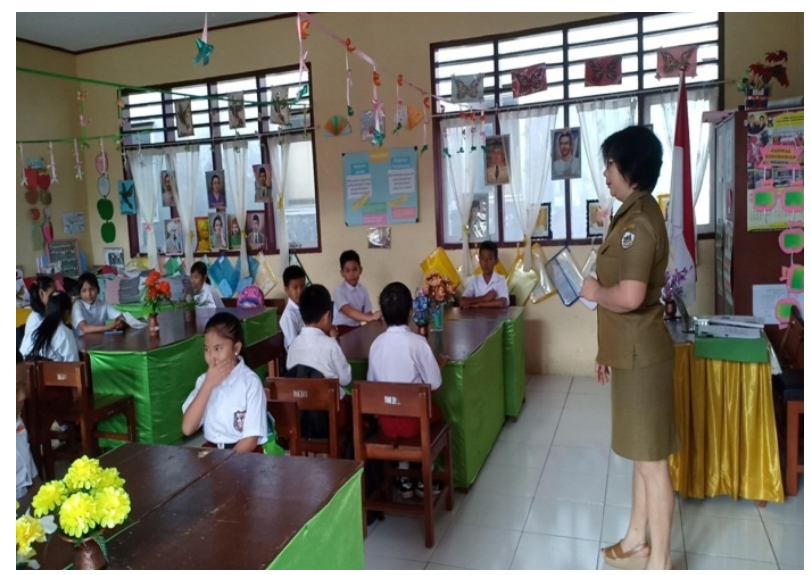

Figure 2. Teacher when opening a Learning Activity

In other aspects, such as the use of media in learning, there has also been a fairly good effort. To find out the existence of this increase can be seen in the table of implementation of learning before and after the action as decomposed as follows:

Table 2. Implementation of SAVI Learning Before and After Actions

\begin{tabular}{|c|c|c|c|c|c|}
\hline \multirow{2}{*}{ No. } & \multirow{2}{*}{$\begin{array}{l}\text { Learning } \\
\text { Components }\end{array}$} & \multicolumn{4}{|c|}{ Learning Activities } \\
\hline & & \multicolumn{2}{|r|}{ Before Actions } & \multicolumn{2}{|r|}{ After Actions } \\
\hline 1. & Curriculum & & idual curriculum for children & & $\begin{array}{l}\text { ot been compiled Already compiled individual } \\
\text { culum for children. }\end{array}$ \\
\hline 2. & Students & & $\begin{array}{l}\text { Not yet got the appropriate learning } \\
\text { strategy (still classical) } \\
\text { Not yet facilitating student reading } \\
\text { difficulties } \\
\text { The child's initial ability has been } \\
\text { developed with the material / material } \\
\text { being studied }\end{array}$ & c. & $\begin{array}{l}\text { Implement the SAVI learning model } \\
\text { Start helping and guiding students with the potential } \\
\text { SAVI learning steps students can maximize } \\
\text { Continue to maintain and develop the child's initial } \\
\text { abilities with the material / material being studied. }\end{array}$ \\
\hline 3. & Teacher & $\begin{array}{l}\text { d. } \\
\text { e. }\end{array}$ & $\begin{array}{l}\text { Two teachers teach } 24 \text { students } \\
\text { The teacher is more dominating the } \\
\text { learning activities and does not involve } \\
\text { student activity } \\
\text { The method used is lecture and question } \\
\text { and answer } \\
\text { Less use of media and props } \\
\text { Have not compiled an individual } \\
\text { curriculum for students }\end{array}$ & & $\begin{array}{l}3 \text { teachers (Ibu NP, and SL, including researchers) } \\
\text { taught } 8 \text { students } \\
\text { Teachers more facilitate learning and involve students } \\
\text { in acquiring knowledge through active interaction. } \\
\text { Using the SAVI method (with Somatic, Audio, Visual } \\
\text { and Intellectual steps), which is varied with questions } \\
\text { and answers, group discussions, assignments and } \\
\text { exercises. } \\
\text { Start using media in the class } \\
\text { Already compile individual student curriculum. }\end{array}$ \\
\hline
\end{tabular}




\begin{tabular}{|c|c|c|c|c|c|}
\hline \multirow{2}{*}{ No. } & \multirow{2}{*}{$\begin{array}{l}\text { Learning } \\
\text { Components }\end{array}$} & \multicolumn{4}{|c|}{ Learning Activities } \\
\hline & & & Before Actions & & After Actions \\
\hline 4. & $\begin{array}{l}\text { Learning } \\
\text { Methods }\end{array}$ & $\begin{array}{l}\text { a. } \\
\text { b. } \\
\text { c. }\end{array}$ & $\begin{array}{l}\text { Only lectures and questions and answers } \\
\text { The approach is always classical } \\
\text { The stages of reading comprehension } \\
\text { activities have not been clearly } \\
\text { implemented } \\
\text { Less involving students to interact with } \\
\text { each other in learning material }\end{array}$ & $\begin{array}{l}\text { c. } \\
\text { d. }\end{array}$ & $\begin{array}{l}\text { Already implementing the SAVI model, varied with } \\
\text { group discussions, exercises and questions and } \\
\text { answers. } \\
\text { Already using a small group approach, and } \\
\text { individually tailored to the difficulties and needs of } \\
\text { students. } \\
\text { Reading activities have begun to systematically start } \\
\text { from Somatis, Audio, Visual, and Intellectual } \\
\text { Already starting to involve students in interacting with } \\
\text { other friends even though there are still many things } \\
\text { that must be directed. }\end{array}$ \\
\hline 5. & Learning Media & $\begin{array}{l}\text { a. } \\
\text { b. }\end{array}$ & $\begin{array}{l}\text { Not yet utilizing existing learning media } \\
\text { There is no learning media created by the } \\
\text { teacher }\end{array}$ & a. & $\begin{array}{l}\text { Already starting to use learning media in the classroom } \\
\text { to help explain the material. } \\
\text { Researchers and teachers together make mind maps } \\
\text { more attractive }\end{array}$ \\
\hline 6. & Parents & $\begin{array}{l}\text { a. } \\
\text { b. }\end{array}$ & $\begin{array}{l}\text { Not yet involved in the preparation of } \\
\text { individual student curricula. } \\
\text { Not yet involved in the learning process } \\
\text { to help students who have not responded } \\
\text { to instruction in learning activities } \\
\text { In some cases there are still less } \\
\text { communicative parents to solve problems } \\
\text { reading students at school. }\end{array}$ & $\begin{array}{l}\text { a. } \\
\text { b. } \\
\text { d. }\end{array}$ & $\begin{array}{l}\text { Already agreed with the preparation of individual } \\
\text { student curriculum. } \\
\text { Already starting to show his involvement in helping } \\
\text { students, but still not maximal. } \\
\text { There seems to be a little effort from parents to handle } \\
\text { difficulties in reading students even though they are not } \\
\text { maximal and still need to be monitored and reminded. }\end{array}$ \\
\hline 7. & Assessment & & $\begin{array}{l}\text { There are no assessment targets that are } \\
\text { adjusted to the students 'reading } \\
\text { comprehension ability. The }\end{array}$ & & $\begin{array}{l}\text { assessment targets have been prepared which are } \\
\text { adjusted to students' reading comprehension abilities }\end{array}$ \\
\hline
\end{tabular}

Although there was an increase in learning activities, there were still some obstacles in the implementation, namely:

a) Not yet able to apply the SAVI learning model to the maximum because it still needs adjustments, especially for NP teachers who teach directly in class. For SL teachers, it is still necessary to establish a deep understanding of the steps of the model used in SAVI's learning. Adequate adjustments are needed to help students have difficulty reading in the classroom, although in some cases many have been helped, for example the teacher's ability to deliver material , the teacher's interaction with students in the class is quite good, and teaching preparation is quite good. But it needs to be strengthened again with the teacher's expertise in using the SAVI learning model, and teacher initiative in developing adaptive learning with students in the class.

b) Characteristics of reading difficulties students who are very diverse in the class influence the adjustment that is not fast in understanding the reading, because at any time there are students who do not understand the contents of the reading, so they ask the group friends or assisted by the teacher. If something like this has happened and to keep learning going on automatically the teacher and other students must be able to help their friends who have difficulty

c) Parents of VP, JT and JN still lacked support for students at home so that during the first cycle, the three students were enough to take the attention of the NP teacher and the SL teacher, during class learning.

d) Although there are obstacles in the implementation of learning, but the support and attention of the school (principals, administrative staff, classroom teachers) is quite positive, making it easier for researchers to communicate the stages of the SAVI learning model, so that achieving the effectiveness of implementing the SAVI learning model can be maximized.

\section{Evaluation}

The results of the pre-test and post-test tests in the first cycle of the SAVI learning model in class IV are: 
Table 3. Learning Outcomes of Students in class IV in cycle 1

\begin{tabular}{|c|c|c|c|c|}
\hline \multirow{2}{*}{ No } & \multirow{2}{*}{ Indicators } & \multirow{2}{*}{$\begin{array}{l}\text { Student } \\
\text { Names }\end{array}$} & \multicolumn{2}{|c|}{ Values } \\
\hline & & & Pre-test & Post-test \\
\hline 1 & \multirow{24}{*}{$\begin{array}{l}\text { in Indonesian } \\
\text { 3.1.1 Identify key ideas and supporting ideas for each paragraph of written text. } \\
\text { 4.1.1 Presenting the main ideas and supporting ideas of each paragraph of the written text } \\
\text { in the form of a mind map. }\end{array}$} & $\mathrm{AK}$ & 30 & 45 \\
\hline 2 & & AA & 40 & 50 \\
\hline 3 & & AN & 30 & 45 \\
\hline 4 & & $\mathrm{AM}$ & 20 & 60 \\
\hline 5 & & AAP & 30 & 60 \\
\hline 6 & & CK & 20 & 65 \\
\hline 7 & & $\mathrm{DM}$ & 30 & 55 \\
\hline 8 & & FM & 30 & 60 \\
\hline 9 & & GT & 20 & 40 \\
\hline 10 & & JS & 25 & 50 \\
\hline 11 & & JT & 20 & 40 \\
\hline 12 & & JK & 30 & 60 \\
\hline 13 & & MW & 35 & 65 \\
\hline 14 & & MM & 40 & 70 \\
\hline 15 & & $\mathrm{PM}$ & 30 & 65 \\
\hline 16 & & PR & 50 & 70 \\
\hline 17 & & $\mathrm{RM}$ & 40 & 60 \\
\hline 18 & & RS & 30 & 60 \\
\hline 19 & & VR & 20 & 55 \\
\hline 20 & & JN & 20 & 50 \\
\hline 21 & & JA & 40 & 65 \\
\hline 22 & & PW & 40 & 70 \\
\hline 23 & & $\mathrm{RL}$ & 30 & 60 \\
\hline 24 & & AS & 30 & 60 \\
\hline
\end{tabular}

\section{Reflection}

The results of the implementation of learning in students with learning difficulties reading in class IV through the application of the SAVI learning model in cycle 1 are as follows:

a. The existence of positive and conducive support from the School (Principal, Administrative Staff, psychologists, other classroom teachers), namely by giving freedom, facilities and infrastructure for the implementation of SAVI learning.

b. The individual curriculum / individual teaching program is prepared for students who are fluent in reading in class IV in accordance with the initial assessment and applying it to SAVI learning activities.

c. The teacher's ability to implement the SAVI learning stages is still not optimal, so that the implementation of learning still requires direction, guidance, and input from the researcher. Especially for intellectual processes that require emphasis so that students will reflect maximally.

d. Because it just adjusts to the stages of the SAVI learning model, students who have difficulty reading still need guidance to begin the initial to the end stages so that their potential utilization can be optimally implemented

e. Lack of parental support for some students in grade IV which has an effect on children's readiness in learning and the smooth implementation of the SAVI learning model in class IV.

f. While attending SAVI learning in class IV in general it can run smoothly. It's just that there are still two students with special needs who always behave hyperactively, thus slightly affecting the classroom atmosphere.

g. Strengthening is always used in class IV especially to provide motivation to students and to shape reading skills in each student. Strengthening is given in the form of verbal and appreciation in the form of stars. For further learning this reinforcement is maintained.

\section{Discusion}

The Effectiveness of Learning in Thematic Learning in 
Students with Difficulty in Reading Class IV Elementary School. The effectiveness of learning is part of the quality standard of education, so the effort to increase the effectiveness of learning is an effort to improve the quality of education. With the creation of quality education, the expected educational goals can be achieved. The initial step to achieving educational goals is the achievement of learning objectives which are referred to as learning outcomes. The first research findings prove that the application of the SAVI learning model is able to make effective learning so that students who have difficulty reading achieve optimal learning outcomes. the findings of this study also prove the findings of Hartati and Sismulyasih (2017) who concluded that the application of SAVI learning models assisted by audio visual was more effective than conventional learning models.(Hartati, Sismulyasih, 2017)

Talking about the effectiveness of learning created in this research is inseparable from the collaboration of stakeholders in this case, researchers, principals, class teachers, special teacher assistants who continuously and also the readiness of teachers in planning learning, preparing media and learning materials, and teacher's ability to manage class. This is like the research findings submitted by Rohmawati (2018) that,

"(1) learning is effective because of the conditioning that is done continuously between the vision and mission of the school in achieving quality education, (2) the existence of readiness of teachers in planning learning and teachers' attitudes and capabilities in providing exemplary in children, (3) the success of parents in achieving effective learning in children can not be separated from their parents upbringing influenced by socio-economic background of the family as well as the intensity of the time spent with the child, (4) the awareness of society in school success petrified organize effective learning, (5) the shape is done with the cooperation of stakeholders to establish communication and involvement in school activities. " (25).

The effectiveness of learning is part of the quality standard of education, so the effort to increase the effectiveness of learning is an effort to improve the quality of education. With the creation of quality education, the expected educational goals can be achieved. The initial step to achieving educational goals is the achievement of learning objectives which are referred to as learning outcomes. The first research findings prove that the application of the SAVI learning model is able to make effective learning so that students who have difficulty reading achieve optimal learning outcomes. the findings of this study also prove the findings of Hartati and Sismulyasih (2017) who concluded that the application of SAVI learning models assisted by audio visual was more effective than conventional learning models (24).

Talking about the effectiveness of learning created in this research is inseparable from the collaboration of stakeholders in this case, researchers, principals, class teachers, special teacher assistants who continuously and also the readiness of teachers in planning learning, preparing media and learning materials, and teacher's ability to manage class.

Application of the SAVI Learning Model Can Improve Learning Outcomes in Thematic Learning in Students with Difficulty in Reading Class IV Elementary Schools. Thematic learning that applies the SAVI learning model in this study is oriented to the learning process where students find knowledge through various physical activities involving various senses, such as observing plants in exploring their relationship with solar energy sources; observing visual texts to understand the benefits of solar energy in daily life; experiments in making windmills; and experiments to find the source of sound and how to propagate sound. The emphasis of learning on inquiry processes increases the courage and self-confidence and interest of students and is able to relate learning material to other subjects, as stated by Schrader, Reichelt, \& Zander, (2018) that learning that emphasizes the inquiry process increases their confidence and interest in teaching science and that process-orientation in science provides a mechanism for integrating science with other subjects. The findings of this study are also in line with research findings (26) Muktadir \& Agustrianto, (2014) which states that thematic learning provides many opportunities for students to be able to participate more and engage in learning activities, thereby increasing the courage and confidence of students who are seen in their enthusiasm in the learning process provide maximum learning results (27).

The assessment carried out in this study consisted of two, namely the assessment of the process and the assessment of learning outcomes, with the aim of evaluating the process of impacting the assessment of learning outcomes, that formative assessment or process assessment can be a powerful tool in regulating student learning approaches that lead to learning outcomes.

Learning outcomes obtained both in cycle 1 theme 1 "Beautiful togetherness" sub theme 1 "Cultur al Diversity of My Nation" and cycle 2 theme 2 "Always save energy" sub Theme 1 "Energy Source" provides provisions for students who have difficulty reading in class IV Tomohon State Elementary School II and Tomohon GMIM III Elementary School to be successful in the world of education as well as in social life. Because through thematic learning that maximizes the function of the senses in the learning that has been passed, students understand the diversity of existing cultures, and also understand and understand their rights and obligations in utilizing energy sources in daily life.

The Learning Process That Applies the SAVI Learning Model to students who have difficulty reading. Difficulty in reading is one of the characteristics of students in inclusive learning in Tomohon Elementary School II and Tomohon Elementary School GMIM III is a challenge for 
classroom teachers in an effort to make students understand the subject matter which is packaged in the form of stories. But through the application of the Somatic Auditory Visual Intelligence (SAVI) learning model that emphasizes learning ranging from moving limbs, seeing, listening and thinking able to make this thematic learning effective and lead students to achieving optimal learning outcomes.

Likewise, the adoption of the 2013 curriculum for the first time in North Sulawesi in the odd semester of the 2017-2018 school year is a welcome for teachers in applying thematic learning with learning content constituting material in various fields of study which are packaged into one theme. In thematic learning, the teacher must really design learning, provide media and teaching materials that are suitable for all fields of study and various instruments or rubric assessments. The implementation of the 2013 curriculum in thematic learning encountered several obstacles on the part of the government, institutions, teachers, parents and students themselves, as stated by (28) The obstacles in applying the 2013 curriculum on the part of teachers were the development of instructional media, teacher understanding, integration content from various subjects in thematic teaching, and IT literacy. The application of the 2013 curriculum in this study also has another challenge, namely the application of the 2013 curriculum in inclusive programs on thematic learning. Challenges or obstacles in inclusive programs such as those proposed by Fitria at all, (2015) are the lack of cooperation between class teachers and special assistant teachers. Learning from the constraints raised by Fitria at all, in this study, before carrying out the teaching of the teachers, training and equating perceptions about the application of the SAVI learning model in learning theme 1 "Beautiful togetherness" sub theme 1 "My Cultural Diversity" and the theme 2 "always save energy" sub theme 1 "energy source". The training activities are intended to assist and guide teacher understanding, assessment methods, development of learning media and integration of content from various fields of study (29)

The skill of asking questions is really needed by teachers in applying SAVI learning because with the right questions both in written and oral form can direct and lead students to understand the subject matter. This is in line with the results of Judiani (2018) research which explains that the questions directed in the discussion foster curiosity of students while learning through experimental activities or observing nature (30).

In applying the SAVI learning model students are invited to find knowledge through learning activities that maximize the functions of the five senses and intellectuals so as to get better learning outcomes. Because the application of the SAVI learning model enhances process skills and also increases the percentage of student learning outcomes such as the results of the study proposed. For example, in finding ways to make sounds, by hitting the drums with your hands, plucking the guitar with your fingers, blowing the flute with your mouth . Through activities that involve them in direct observation, students are invited to be critical and ask quality questions that themselves can help them find answers that are learning objectives that is the knowledge they must have

The application of the SAVI learning model in this study has the specificity of using a group approach in the learning process. Maximizing group functions in the thematic learning process with the aim of building knowledge is a step taken in order to anticipate the characteristics of existing students namely reading difficulties. This step is taken with the assumption that the learning target that must be completed in one day is that one learning can be completed. Because if the individual approach is used, there is a possibility that the targeted time is not enough, as found one material in one day. This is an obstacle because in one day the teacher may not be able to complete one material for normal students especially if in inclusive learning there are some students who have difficulty learning to read.

In addition to the group approach and the process approach taken to maximize the achievement of learning outcomes in thematic learning with the characteristics of students having difficulty reading in this inclusive learning program, visual text is also used as a medium and learning material. The visual text is intended to help minimize the obstacles students who have difficulty reading to understand the material diversity of my nation's culture and energy source material. The use of visual texts on learning that is set in a group approach is part of the use of multi-censorship education programs, such as the solutions offered

Effective learning is closely related to maximum learning outcomes, or in other words effective learning is able to provide maximum learning outcomes for students. Effective learning can be achieved by effective teachers too. The SAVI learning model in Thematic learning is the teacher known as an educator. Collaboration between class teacher and special teacher in implementing learning, conducting intensive mentoring, as well as assessing the thematic learning process theme 1 "The beauty of togetherness" sub theme 1 "Diversity of My Nation's Culture" and theme 2 "Always saving energy" sub Theme 1 " Energy Sources "provides optimal learning outcomes for students who have difficulty reading in class IV Tomohon Public Elementary School II and Tomohon Elementary School GMIM III. This collaboration between classroom teachers and special assistant teachers is in line with Hidayah's research findings (2011) that inclusive learning for students with special needs in this case reading difficulties require special treatment that is special teacher assistants.

\section{Conclusions}

Based on data analysis and discussion, the following 
conclusions can be drawn.

a. Thematic learning outcomes in students having difficulty reading grade IV Tomohon Public Elementary School II and Tomim Elementary School GMIM III can be improved through the application of the SAVI learning model.

b. The learning process that applies the SAVI Learning Model is able to overcome the difficulty of reading students to understand the subject matter by learning from moving, observing, listening and thinking so that learning and learning outcomes improve.

c. The effectiveness of thematic learning in students having difficulty reading grade IV SD Negeri II Tomohon and SD GMIM III Tomohon can be improved through the application of the SAVI learning model.

\section{Acknowledgements}

This research sponsored by Universitas Negeri Manado.

\section{REFERENCES}

[1] Abdurahman M. Anak Berkesulitan Belajar: Teori, Diagnosis dan Remediasinya. Jakarta: Rieneka Cipta; 2012. $157 \mathrm{p}$.

[2] Jamaris M. Kesulitan Belajara. Perpektif, Asesmen dan Penanggulangannya. Bogor: Ghalia Indonesia; 2015. 145 p.

[3] Sutikno MS. Metode \& Model-Model Pembelajaran. Lombok: Holistica; 2014. 35 p.

[4] Suyatno. Teknik Pembelajaran Bahasa dan Sastra. Surabaya: Penerbit SIC; 2014. 15 p.

[5] Shodiq M. Pendidikan Bagi Anak berkesulitan belajar membaca. Jakarta: Dirjen Dikti Depdikbud PPTA; 1996.

[6] Mills Geoffrey E. Action Research; A Guide For The Teacher Researcher; Second Edition. Boston: Pearson Education, Inc.; 2003. 5 p.

[7] Norman K. Denzin YSL. Handbook of Qualitative Research: Edisi Bahasa Indonesia. Yogyakarta: Pustaka Pelajar; 2009. $438 \mathrm{p}$.

[8] Suharsimi Arikunto, Suhardjono S. Penelitian Tindakan Kelas. Jakarta: PT. Bumi Aksara; 2008. 64 p.

[9] Zuber, Ortrun S. Ortrun, Skerrit. London: Falmers Press; 1996. 9 p.

[10] Susiolo. Panduan Penelitian Tindakan. Yogyakarta: Pustaka Book Publisher; 2007. 6 p.

[11] Hopkins D. A Theacher' Guide to Classroom Research, third edition. Philadelphia: Buckingham-Open University Press; 2002. 43 p.

[12] Brannick, David Coghlan T. Doing Action Research in Your Own Organization, Second Edition. London: Sage
Publication Ltd; 2005. 3 p.

[13] D. Mercer-Cecil dan RM-A. Teaching Students with Learning Problems, third edition. USA: Merril Publishing Company A Bell \& Howell Company; 1989. 99 p.

[14] Hargrove P. Asessment in Special Education: The Education Evaluation. New Jersey: Prentice- Hall Inc; 1984. 164 p.

[15] Yusuf M. Pendidikan Bagi Anak Dengan Problem Belajar. Jakarta: Depdiknas; 2015. 16 p.

[16] Wahyudi RK. Gambaran Sekolah Inklusif di Indonesia. Jakarta: Kemendikbud; 2016. 9 p.

[17] Stainback, S WS. In The inclusion papers: Strategies to make inclusion work, ed . J. Pearp oint, M. Fores t, and J. Snow. Toronto: Inclusion Press:; 1992. vii.

[18] Bradley D. Moving into the mainstream. Educ Forum. 1995;59(1):81-91.

[19] Yusuf, Munawir D. Pendidikan Inklusif Dan Perlindungan Anak. Solo: Metagraf; 2018. 236 p.

[20] Rusmono. Learning Strategy with Problem Based Learning Needed. Jakarta: Ghalia Indonesia; 2012.

[21] De Houwer, J., Barnes-Holmes, D. and Moors A. What is learning? On the nature and merits of a functional definition of learning. Psychon Bull Rev. 2013;20(4):631-42.

[22] Amstrong M dan B. Performance Management. Alih Bahasa: Toni Setiawan. Yogyakarta: Tugu Publisher; 2004.

[23] Gargiulu RM. Special Education in Contemporary Society. California: Sage Publication; 2012. 4 p.

[24] Hartati NS. "Development of SAVI (Somatic Auditory Visual and Intellectual)Learning Model with Audiovisual to Increase Writing Skill of Elementary Student”. In: Proceeding: 9th International Conference for Science Educators and Teachers (ICSET), Advances in Social Science, Education and Humanities Research [Internet]. 2017. Available from: https://www.atlantis-press.com/proc eedings/icset-17/25886674

[25] Widiyanto R, Saprudin, Imswatama A. kelayakan isi buku teks bahasa indonesia kelas X edisi revisi 2016 ditinjau dari implikasi pendekatan saintifik pada kurikulum 2013 revisi. DWIJA CENDEKIA J Ris Pedagog 2. 2018;2(1):43-51.

[26] Schrader C, Reichelt M, Zander S. The effect of the personalization principle on multimedia learning: the role of student individual interests as a predictor. Educ Technol Res Dev. 2018;66(6):1387, 1387-97.

[27] Muktadir A, Agustrianto. Jurnal Pendidikan Karakter. Pengemb Model Mata Pelajaran Muatan Lokal Berbas Kearifan Lokal Untuk Meningkat Karakter Di Sekol Dasar Provinsi Bengkulu. 2014;Tahun IV:318-31.

[28] Kristiana A. Peningkatan Keterampilan Proses Sains Melalui Pembelajaran Berbasis Laboratorium Untuk Mewujudkan pembelajaran Berkarakter. 2017;4(2):60-5.

[29] Wayas Shirly Amaris, Fitria Akhyar EYH. Pengaruh Penggunaan Sumber Belajar Terhadap Prestasi Belajar IPS. J Pedagog. 2015;3(5):1.

[30] Judiani S. Implementasi Pendidikan Karakter di Sekolah Dasar Melalui Penguatan Pelaksanaan Kurikulum. J Pendidik dan Kebud. 2018; 